\title{
Essential oils for the postharvest control of blue mold and quality of 'Fuji' apples
}

\author{
Amanda Maria Furtado Drehmer Vieira( ${ }^{(1)}$, Cristiano André Steffens ${ }^{(1)}$, Luiz Carlos Argenta( ${ }^{(1)}$, \\ Cassandro Vidal Talamini do Amarante ${ }^{(1)}$, Andreia Hansen Oster ${ }^{(2)}$, Ricardo Trezzi Casa ${ }^{(1)}$, \\ Antônio Gabriel Mortari Amarante ${ }^{(1)}$ and Bruno Pansera Espíndola ${ }^{(1)}$
}

\begin{abstract}
(1)Universidade do Estado de Santa Catarina, Centro de Ciências Agroveterinárias, Avenida Luiz de Camões, no2.090, CEP 88520-000 Lages, SC, Brazil. E-mail: amanda.drehmer@udesc.br, cristiano.steffens@udesc.br, argenta@epagri.sc.gov.br, cassandro.amarante@udesc.br, ricardo.casa@udesc.br, gabriel-amarante@hotmail.com, brunopansera@hotmail.com ${ }^{(2)}$ Embrapa Agroindústria Tropical, Rua Dra. Sara Mesquita, no 2.270, CEP 60511-110 Fortaleza, CE, Brazil. E-mail: andreia.hansen@embrapa.br
\end{abstract}

Abstract - The objective of this work was to evaluate the effect of rosemary, cinnamon, citronella grass, and clove essential oils on the in vitro growth of Penicillium expansum, on the diameter of blue mold lesions, and on the physical and chemical attributes of 'Fuji' apples stored under refrigeration for different periods of time. The compositions of the essential oils were determined, and their effects on the growth inhibition, number, and viability of fungal spores in vitro were evaluated at 0,100 , and $1,000 \mu \mathrm{L} \mathrm{L}^{-1}$ oil concentrations. At postharvest, evaluations were performed for fruit treated with $0,50,100$, and $500 \mu \mathrm{L} \mathrm{L}^{-1}$ essential oil and kept under refrigeration for 30 days, and for fruit treated with 0,100 , and $500 \mu \mathrm{L} \mathrm{L}^{-1}$ oil and kept under refrigeration for two days. The essential oils - eucalyptol (rosemary), eugenol (cinnamon), citronellal (citronella), and eugenol (clove) - reduce the growth, number, and viability of P. expansum spores 24 hours after the induction to germination, as well as the diameter of blue mold lesions in apples, except for citronella oil at $500 \mu \mathrm{L}$ $\mathrm{L}^{-1}$ after 30 days of cold storage. There are no changes in the physicochemical attributes of apples, treated with different concentrations of the oils after refrigeration for five months, followed by seven days at room temperature.

Index terms: Malus domestica, Penicillium expansum, Rosmarinus officinalis, fruit rot.

\section{Óleos essenciais para o controle pós-colheita do mofo-azul e a qualidade de maçãs 'Fuji'}

Resumo - O objetivo deste trabalho foi avaliar o efeito de óleos essenciais de alecrim, canela, citronela e cravo-da-índia sobre o crescimento de Penicillium expansum in vitro, o diâmetro de lesões de mofoazul e os atributos físico-químicos em maçã 'Fuji', armazenada sob refrigeração por diferentes períodos. As composições dos óleos essenciais foram determinadas, e seus efeitos sobre a inibição do crescimento, o número e a viabilidade de esporos do fungo in vitro foram avaliados quanto às concentrações de 0,100 e 1.000 $\mu \mathrm{L} \mathrm{L}^{-1}$. No período pós-colheita, avaliaram-se os frutos tratados com $0,50,100$ e $500 \mu \mathrm{L} \mathrm{L}^{-1}$ de óleo essencial e armazenados sob refrigeração por 30 dias e os frutos tratados com 0,100 e $500 \mu \mathrm{L} \mathrm{L}^{-1}$ de óleo essencial e mantidos sob refrigeração por dois dias. Os óleos essenciais - eucaliptol (alecrim), eugenol (canela), citronelal (citronela) e eugenol (cravo) - reduzem o crescimento, o número e a viabilidade de esporos de $P$. expansum 24 horas após o estímulo à germinação, bem como o diâmetro de lesões de mofo-azul em maçãs, à exceção do óleo de citronela a $500 \mu \mathrm{L} \mathrm{L}^{-1}$, após 30 dias de armazenamento refrigerado. Não há alteração dos atributos físico-químicos de maçãs tratadas com diferentes concentrações dos óleos, após a refrigeração por cinco meses, seguida de sete dias à temperatura ambiente.

Termos para indexação: Malus domestica, Penicillium expansum, Rosmarinus officinalis, podridão de fruto.

\section{Introduction}

Long periods of storage time and exposure on market shelves can cause 'Fuji' apples to have high loss rates, from 12 to $20 \%$, depending on the time of year and region of cultivation in Brazil (Argenta et al.,
2015). Penicillium expansum Link, 1809 (blue mold) and Cryptosporiopsis perennans (Zeller \& Childs) Wollenweber, 1939 (bull's eye rot) are among the most significant causes for rot in 'Fuji' apples. According to Medeiros (2015), losses caused by blue mold during cold storage can reach $13 \%$. 
The use of postharvest fungicides is not always efficient to control the major rots, and their use in pre and postharvest may constitute environmental and toxicological risks (Neri et al., 2006). In addition, some countries, such as Italy, reported the occurrence of $P$. expansum strains resistant to fungicides of the benzimidazole group (Neri et al., 2006).

The need to find alternative solutions for the chemical control of diseases results from the growing concern about the environment, the purchase of pesticidefree fruits, and the demand for healthy products by consumers. In addition, the food production industry is concerned about cases of food contamination caused by bacteria such as Listeria monocytogenes, Escherichia coli, and Salmonella spp., and fungi such as Colletotrichum spp. and Penicillium spp. in countries such as New Zealand and USA (Popa et al., 2007; Miller et al., 2013).

Therefore, the positive effects of essential oils of plant species, or their components, on the control of fungi, bacteria, and viruses, have been reported in the literature. Tao et al. (2014) observed that the essential oil of Citrus reticulata inhibited the growth of Penicillium italicum and $P$. digitatum in vitro, and altered the morphology of hyphae and the integrity of the fungal plasma membrane. Rosemary oil caused extravasation of cellular fluid and inhibited the growth of Fusarium verticillioides (Bomfim et al., 2015). Essential oils of thyme, oregano, and lemon grass incorporated into the culture medium completely inhibited the in vitro growth of Botrytis cinerea and Alternaria arborescens; the vaporization of thyme and oregano essential oils inhibited the growth of Rhizopus stolonifer by 69 and $64 \%$, respectively (Plotto et al., 2003). Sun et al. (2014) observed a reduced growth of Escherichia coli and $P$. digitatum both in vivo and in vitro, in the presence of carvacrol, cinnamaldehyde, and trans-cinnamaldehyde, major compounds of some essential oils such as cinnamon, clove, oregano, and thyme. However, the inhibitory effect on growth, morphology alteration of hyphae, and rupture of microorganism membranes can be different depending on the essential oil, the concentration used, and the pathogen under study (Plotto et al., 2003; Droby et al., 2008; Lorenzetti et al., 2011; Sun et al., 2014; Bomfim et al., 2015).

Despite the publication of several reports on the action of essential oils on microorganisms in vitro, little is known about their effects on the development of postharvest pathogens in fruits and on what changes occur in their physicochemical characteristics.

The objective of this work was to evaluate the effect of rosemary, cinnamon, citronella grass, and clove essential oils on the in vitro growth of Penicillium expansum, on the diameter of blue mold lesions, and on the physical and chemical attributes of 'Fuji' apples stored under refrigeration for different periods of time.

\section{Materials and Methods}

Three experiments were carried out - one in vitro and two in vivo, with essential oils of rosemary (Rosmarinus officinalis L.), cinnamon (Cinnamomum zeylacium Blume), citronella grass (Cymbopogon winterianus Jowitt), and clove (Syzigium aromaticum L.).

The aromatic compounds present in the essential oils were quantified at the chemistry laboratory of natural products of Embrapa Agroindústria Tropical, located in the municipality of Fortaleza, $\mathrm{CE}$, Brazil. These compounds were analyzed through gas chromatography/mass spectrometry using the GC-7890B/MSD-5977A quadrupole (Agilent, Santa Clara, CA, USA), with identification by the Kovats index in a HP-5 column and calculation of the relative area of each compound (Ribeiro et al., 2015).

In the first experiment, essential oils at 100 and $1,000 \mu \mathrm{L} \mathrm{L}^{-1}$ were volatilized in Petri dishes with the fungus $P$. expansum. Adhesives containing the essential oils were placed in the internal part of the lid of each dish containing a PDA culture medium. The amount of essential oil needed to reach the concentrations was determined according to the formula: $\mathrm{C} 1 \times \mathrm{V} 1=\mathrm{C} 2 \times \mathrm{V} 2$, in which $\mathrm{C} 1$ is the desired concentration of essential oil $\left(\mu \mathrm{L} \mathrm{L}^{-1}\right)$; V1 is the free volume in the Petri dish, obtained by subtracting the volume of culture medium placed in the Petri dish of $0.006 \mathrm{~L}$ from the total volume of the Petri dish of $0.012 \mathrm{~L}$; $\mathrm{C} 2$ is the concentration of the oil $(100 \%)$; and V2 is the value to be calculated - the volume of oil needed to reach the concentration desired inside the Petri dish. An adhesive containing sterilized distilled water was used in the control treatment. Discs of $0.7 \mathrm{~cm}$ diameter containing PDA medium with pure $P$. expansum isolate from ten-day old colonies were placed on each dish. The Petri dishes were placed in growth chambers at $23^{\circ} \mathrm{C}$ and subjected to a 12-hour photophase. After ten days, the number 
and viability of spores were evaluated. On the sixth and tenth day, the colony diameters were measured to obtain growth inhibition, calculated by the formula $\mathrm{IC}(\%)=[(\mathrm{Dc}-\mathrm{Dt}) / \mathrm{Dc}] \times 100$, in which $\mathrm{Dc}(\mathrm{cm})$ is the colony diameter of the control treatment; and $\mathrm{Dt}$ (cm) is the diameter of colony with the essential oil treatments.

To determine the number of spores, $5 \mathrm{~mL}$ of a Tween 20 solution $(0.05 \%)$ and sterile distilled water were placed on the $P$. expansum colonies. The number of spores was counted using a Neubauer chamber (hemacytometer) and an optical microscope, and the result was multiplied by 10,000 to obtain the number of spores per microliter of suspension (Fernandez, 1993).

The conidia viability (\%) was evaluated after 24 or 48 hours, in Petri dishes with agar-water, using $0.5 \mathrm{~mL}$ of the spore suspension. The dishes were sealed and incubated in a growth chamber at $23^{\circ} \mathrm{C}$ and subjected to a 12-hour photophase. Spores were considered viable when they had germ tubes equal to or greater than their size.

For the experiments 2 and 3, 'Fuji' apples were harvested at the ideal maturation point in a commercial orchard in the municiaplity of Vacaria, in the state of Rio Grande do Sul, Brazil, and placed in a specific tray to hold 100 apples. Excessively large or small fruit were removed by visually selecting those of uniform size. In order to ensure that all fruit were similar in all treatments, after the homogenization of the samples, they were disinfested in a sodium hypochlorite solution $\left(1 \%, \mathrm{v} \mathrm{v}^{-1}\right)$ for $3 \mathrm{~min}$, and washed with sterile distilled water to remove the solution residues. Then, they were dried for 2 hours at room temperature $\left(23 \pm 1^{\circ} \mathrm{C}\right)$. The fruit were drilled $-2 \mathrm{~mm}$ diameter and $4 \mathrm{~mm}$ deep - in the equatorial region, using an electronic texturometer (TAXT-plus, Stable Micro System, Surrey, UK), and $10 \mu \mathrm{L}$ of a suspension of $10^{6}$ spores $\mathrm{mL}^{-1}$ of P. expansum were placed in the holes.

In the experiment 2 , the fruit were treated under refrigeration at $0 \pm 0.5^{\circ} \mathrm{C}$ and $90 \pm 2 \%$ relative humidity (RH) for 30 days, using the essential oils at $0,50,100$, and $500 \mu \mathrm{L} \mathrm{L}^{-1}$. The essential oils were applied by volatilization in plastic containers with $4.1 \mathrm{~L}$ capacity. Ten fruit, weighing approximately $140 \mathrm{~g}$ each, were placed in each container. Then the volume of essential oil necessary to reach the desired concentrations was added, according to the formula previously described for the experiment 1 . The containers were sealed with moldable polyvinyl chloride (PVC) plastic film to ensure that there was no change in the internal atmosphere of the containers. After the treatment with the essential oils, the fruit infected prior to treatment were removed from the refrigerator and the diameter of the blue mold lesions $(\mathrm{cm})$ were evaluated daily, for five days, at room temperature $\left(22 \pm 4^{\circ} \mathrm{C}\right.$ and $\left.70.5 \% \mathrm{RH}\right)$.

In the experiment 3 , the fruit remained under atmosphere containing 0,100 , or $500 \mu \mathrm{L} \mathrm{L}^{-1}$ of the volatilized essential oils, at $0 \pm 0.5^{\circ} \mathrm{C}$ and $90 \pm 2 \% \mathrm{RH}$, for two days. The infected fruit were stored for a further 43 days without the essential oils, totaling 45 days of cold storage, and then the diameter of the blue mold lesions $(\mathrm{cm})$ were evaluated for six days at room temperature $\left(22 \pm 4^{\circ} \mathrm{C}\right.$ and $\left.70.5 \% \mathrm{RH}\right)$.

In the experiments 2 and 3 , after the treatment with essential oils, noninfected fruit were stored for five months under refrigeration, followed by seven days storage at room temperature. After this period, pulp firmness, soluble solids (SS), titratable acidity (AT), and background color of the epidermis ( $\mathrm{L}=$ brightness, $\mathrm{C}=$ color, and $\mathrm{h}^{\circ}=$ hue angle hue) were evaluated according to the methodology described by Silveira et al. (2014).

All experiments were conducted in a completely randomized design. In the experiment 1, ten Petri dishes were used per treatment, and each one represented a replicate. In the experiments 2 and 3, four replicates were used, and each ten-fruit container represented one replicate. Data were subjected to the analysis of variance, and the means were compared by the Tukey's test, at 5\% probability, using the SAS program (SAS Institute, Inc., Cary, NC, USA). To estimate the rate at which the rot evolved in the experiments 2 and 3, data on the lesion diameter $(\mathrm{cm})$ were subjected to the linear regression analysis, and the angular coefficients of the lines (b) were compared two-by-two by the Student's t-test. The data percentages were transformed by the equation sine $\operatorname{arc}(\mathrm{y} / 100)^{1 / 2}$.

\section{Results and Discussion}

The analysis of the chemical composition of the essential oils showed a broad range of components, in varying amounts (Table 1). A total of 5 components were found in clove essential oil, and 23 components in citronella grass essential oil. The essential oils have a complex chemical composition, represented mainly by

Pesq. agropec. bras., Brasília, v.53, n.5, p.547-556, May 2018 DOI: $10.1590 / \mathrm{S} 0100-204 X 2018000500003$ 
hydrocarbons (terpenes and terpenoids) and phenolic essential oils showed $87 \%$ phenolic compounds compounds (Tao et al., 2014). Clove and cinnamon (phenylpropanoids) in their composition, and eugenol

Table 1. Chemical composition of rosemary (Rosmarinus officinalis), cinnamon (Cinnamomum zeylacium), citronella grass (Cymbopogon winterianus), and clove (Syzigium aromaticum) essential oils.

\begin{tabular}{|c|c|c|c|c|c|c|}
\hline \multirow[t]{2}{*}{ Compound $^{(1)}$} & \multirow[t]{2}{*}{ KI } & \multicolumn{4}{|c|}{ Relative area (\%) } & \multirow[t]{2}{*}{ Class } \\
\hline & & Rosemary & Cinnamon & Citronella grass & Clove & \\
\hline$\alpha$-pinene & 939 & 13.6 & 0.81 & - & - & Monoterpene \\
\hline Camphene & 954 & 2.94 & 0.25 & - & - & Monoterpene \\
\hline$\beta$-pinene & 979 & 7.08 & 0.21 & - & - & Monoterpene \\
\hline$\beta$-myrcene & 990 & 0.72 & - & - & - & Monoterpene \\
\hline$\alpha$-phellandrene & 1,002 & 0.14 & 0.96 & - & - & Monoterpene \\
\hline$\alpha$-terpinene & 1,017 & 0.28 & - & - & - & Monoterpene \\
\hline$\rho$-cimene & 1,024 & 1.27 & 0.85 & - & - & Monoterpene \\
\hline Limonene & 1,029 & 2.43 & - & 3.20 & - & Monoterpene \\
\hline Eucalyptol & 1,031 & 48.15 & - & - & - & Monoterpenoid \\
\hline$\gamma$-terpinene & 1,059 & 0.41 & - & - & - & Monoterpene \\
\hline Terpinolene & 1,088 & 0.17 & - & - & - & Monoterpene \\
\hline Linalol & 1,098 & 0.77 & 1.59 & 0.52 & - & Monoterpene \\
\hline Camphor & 1,146 & 15.44 & - & - & - & Monoterpenoid \\
\hline Isopulegol & 1,149 & - & - & 0.87 & - & Monoterpene \\
\hline Citronellal & 1,153 & - & - & 36.18 & - & Monoterpenoid \\
\hline Iso-isopulegol & 1,159 & - & - & 0.53 & - & Monoterpene \\
\hline Borneol & 1,169 & 1.67 & - & - & - & Monoterpenoid \\
\hline Terpinen-4-ol & 1,177 & 0.32 & - & - & - & Monoterpenoid \\
\hline$\alpha$-Terpineol & 1,188 & 0.83 & - & - & - & Monoterpenoid \\
\hline Citronellol & 1,225 & - & - & 12.82 & - & Monoterpene \\
\hline Geraniol & 1,252 & - & - & 18.85 & - & Monoterpenoid \\
\hline Geranial & 1,267 & - & - & 0.44 & - & Monoterpenoid \\
\hline E-cinnamaldehyde & 1,270 & - & 0.94 & - & - & Phenylpropanoid \\
\hline Safrole & 1,287 & - & 1.09 & - & - & Phenylpropanoid \\
\hline Bornyl acetate & 1,288 & 0.28 & - & - & - & Phenylpropanoid \\
\hline Citronellol acetate & 1,352 & - & - & 3.60 & - & Monoterpene \\
\hline Eugenol & 1,359 & - & 82.68 & 0.68 & 85.27 & Phenylpropanoid \\
\hline Geranyl acetate & 1,381 & - & - & 2.87 & - & Monoterpene \\
\hline$\beta$-elemenone & 1,390 & - & - & 3.00 & - & Sesquiterpene \\
\hline Trans- $\beta$-caryophyllene & 1,419 & 3.52 & 3.42 & - & 11.47 & Sesquiterpene \\
\hline Trans-cinnamyl acetate & 1,446 & - & 1.17 & - & - & Phenylpropanoid \\
\hline$\alpha$-caryophyllene & 1,454 & - & - & - & 1.31 & Sesquiterpene \\
\hline Allo-aromadendrene & 1,460 & - & 0.53 & - & - & Sesquiterpene \\
\hline Germacrene-D & 1,484 & - & - & 2.13 & - & Sesquiterpene \\
\hline$\alpha$-muurolene & 1,500 & - & - & 0.92 & - & Sesquiterpene \\
\hline Germacrene-A & 1,509 & - & - & 0.60 & - & Sesquiterpene \\
\hline$\gamma$-cadinene & 1,513 & - & - & 0.91 & - & Sesquiterpene \\
\hline Eugenol acetate & 1,522 & - & 2.25 & - & - & Phenylpropanoid \\
\hline$\delta$-cadinene & 1,523 & - & - & 3.52 & 0.25 & Sesquiterpene \\
\hline Elemol & 1,549 & - & - & 4.24 & - & Sesquiterpene \\
\hline Germacrene-D-4-ol & 1,575 & - & - & 0.70 & - & Sesquiterpene \\
\hline Caryophyllene oxide & 1,583 & - & - & - & 0.28 & Sesquiterpene \\
\hline$\gamma$-eudesmol & 1,632 & - & - & 0.52 & - & Sesquiterpenoid \\
\hline Muurolol & 1,646 & - & - & 0.93 & - & Sesquiterpenoid \\
\hline$\beta$-eudesmol & 1,650 & - & - & 0.51 & - & Sesquiterpenoid \\
\hline$\alpha$-eudesmol & 1,653 & - & - & 1.45 & - & Sesquiterpenoid \\
\hline Benzyl benzoate & 1,760 & - & 3.24 & - & - & Phenylpropanoid \\
\hline
\end{tabular}

${ }^{(1)}$ Compounds listed in increasing order of Kovats index. KI, Kovats index on an HP-5 column. 
was the main one $(86.6 \%$ and $82.7 \%$, respectively). Bakkali et al. (2008) also found phenolic compounds in clove, cinnamon, and nutmeg essential oils as their main composition, and cinnamaldehyde was the major phenolic compound in cinnamon essential oil. However, cinnamon essential oil used in the present work had more than $80 \%$ eugenol and less than $1 \%$ cinnamaldehyde in its composition. Some studies have reported that the extraction method (Fisher \& Phillips, 2008), climatic and agronomic factors - such as fertilization, irrigation, and plant development phase at the time of extraction (Masotti et al., 2003) -, as well as the plant part used for extraction (roots, fruits, leaves, or stems) could affect the composition of essential oils (Varughese et al., 2016).

Terpenoids may be the main components of some essential oils, as observed for citronella grass and rosemary oils (Table 1). In citronella grass oil, approximately $60 \%$ of terpenoids and $40 \%$ of terpenes were identified, and citronellal, geraniol, and citronellol were the major compounds with relative proportions of $36.2,18.9$, and 12.8, respectively. Castro et al. (2007) identified 15 compounds in citronella grass essential oil, with the same major compounds in relative proportions, similarly to those identified in the present study. In rosemary essential oil, 18 compounds, such as eucalyptol, camphor, and $\alpha$-pinene were identified as the main components, with relative concentrations of $48.2,15.4$, and $13.6 \%$, respectively. Bomfim et al. (2015) identified 24 compounds in rosemary essential oil, with the same main components at similar relative concentrations.

It is important to note that the composition of all the essential oils analyzed here showed one to three major compounds and several others, at concentrations equal to or less than $1 \%$ (Table 1). The efficiency of some compounds isolated from essential oils of different plant species has been reported for the control of fungi, such as octane (Tao et al., 2014), trans-2-hexanal (Neri et al., 2006), eugenol, cinnamaldehyde, and carvacrol (Sun et al., 2014), which are major compounds in essential oils.

Various components present in essential oils could show synergism in the control of microorganisms (Bakkali et al., 2008). The activity of the major compounds is probably articulated by minority molecules (Hoet et al., 2006). Many of these minor compounds are responsible for the definition of aroma, density, texture, and color of oils. In addition, there are important characteristics of these minor compounds for the control of microorganisms, such as cell penetration, lipophilic and hydrophilic action, attachment to cell wall and membrane, and distribution of the compounds of fungicidal or fungistatic action in the fungal cell (Bakkali et al., 2008).

All essential oils had a reducing effect on the growth of $P$. expansum, both in vitro (Table 2) and in vivo, except for rosemary oil at $100 \mu 1 \mathrm{~L}^{-1}$ (Figure 1), but this effect varied depending on the oil, concentration, and exposure time. Despite the nonsignificant result of the rosemary essential oil at $100 \mu \mathrm{L} \mathrm{L}^{-1}$ for the inhibition of $P$. expansum growth, it significantly reduced the number of fungal spores at this concentration (Table 2). However, the viability did not differ from the control after 24 and 48 hours of induction to germination. Cinnamon, citronella grass, and clove oils reduced spore viability from 58 to $63 \%$, after 24 hours of induction to germination; however, after 48 hours of induction, viability did not differ from that of the

Table 2. Growth inhibition (GI) at six and ten days after incubation (PDA at $23^{\circ} \mathrm{C}$ and 12 -hour photophase), and number and viability of Penicillium expansum spores, 24 and 48 hours after induction to germination, incubated for ten days (PDA, $23^{\circ} \mathrm{C}$, and 12-hour photophase), depending on volatilized essential oils at 100 and $1,000 \mu \mathrm{L} \mathrm{L}^{-1}$ concentrations ${ }^{(1)}$.

\begin{tabular}{|c|c|c|c|c|c|}
\hline \multirow{2}{*}{$\begin{array}{l}\text { Oil } \\
\text { essential }\end{array}$} & \multicolumn{2}{|c|}{ GI $(\%)$} & \multirow{2}{*}{$\begin{array}{c}\text { Spores } \\
\mathrm{mL}^{-1}\left(\times 10^{6}\right)\end{array}$} & \multicolumn{2}{|c|}{ Spore viability $(\%)$} \\
\hline & 6 days & 10 days & & 24 hours & 48 hours \\
\hline & \multicolumn{5}{|c|}{ Concentration $100 \mu \mathrm{L} \mathrm{L}^{-1}$} \\
\hline Control & $0 \mathrm{~b}$ & $0 \mathrm{~b}$ & $154.5 \mathrm{a}$ & $97 \mathrm{a}$ & $100 \mathrm{a}$ \\
\hline Rosemary & $11 b$ & $12 b$ & $57.9 \mathrm{~b}$ & $87 \mathrm{ab}$ & $97 \mathrm{a}$ \\
\hline Cinnamon & $78 \mathrm{a}$ & $76 \mathrm{a}$ & $20.4 \mathrm{c}$ & $63 \mathrm{bc}$ & $78 \mathrm{a}$ \\
\hline Citronella grass & $57 \mathrm{a}$ & $59 a$ & $47.9 \mathrm{bc}$ & $62 \mathrm{bc}$ & $92 \mathrm{a}$ \\
\hline Clove & $67 a$ & $63 a$ & $34.7 \mathrm{bc}$ & $58 \mathrm{c}$ & $83 a$ \\
\hline Mean & 43 & 42 & 63.1 & 73 & 90 \\
\hline \multirow[t]{2}{*}{ SD } & 34.8 & 33.7 & 53.0 & 17 & 9 \\
\hline & \multicolumn{5}{|c|}{ Concentration $1.000 \mu \mathrm{L} \mathrm{L}^{-1}$} \\
\hline Control & $0 \mathrm{c}$ & $0 \mathrm{c}$ & $153.2 \mathrm{a}$ & $93 a$ & $100 \mathrm{a}$ \\
\hline Rosemary & $80 \mathrm{~b}$ & $67 b$ & $1.7 \mathrm{~b}$ & $0 \mathrm{~b}$ & $53 \mathrm{ab}$ \\
\hline Cinnamon & $100 \mathrm{a}$ & $100 \mathrm{a}$ & $3.1 \mathrm{~b}$ & $3 b$ & $67 \mathrm{ab}$ \\
\hline Citronella grass & $100 \mathrm{a}$ & $100 \mathrm{a}$ & $0.7 \mathrm{~b}$ & $2 b$ & $92 \mathrm{a}$ \\
\hline Clove & $100 \mathrm{a}$ & $100 \mathrm{a}$ & $2.4 \mathrm{~b}$ & $\mathrm{Ob}$ & $23 b$ \\
\hline Mean & 80 & 73 & 32.2 & 20 & 67 \\
\hline SD & 43.3 & 43.4 & 67.7 & 41 & 31 \\
\hline
\end{tabular}

${ }^{(1)}$ Means followed by equal letters, in the columns at each concentration, do not differ by Tukey's test, at 5\% probability. Control, sterilized distilled water. SD, standard deviation. 
control. Bomfim et al. (2015) reported that rosemary essential oil $\left(150 \mu \mathrm{g} \mathrm{ml}^{-1}\right)$ has a fungitoxic effect on the in vitro growth of Fusarium verticillioides, and inhibits the fungus mycotoxin production (fumonisins).

The concentration of $1,000 \mu \mathrm{L} \mathrm{L}^{-1}$ of rosemary essential oil inhibited 80 and $67 \%$ of in vitro growth of $P$. expansum after 6 and 10 days of incubation, respectively, and differed from the $100 \%$ growth inhibition promoted by oils of the cinnamon, citronella grass, and clove (Table 2). The essential oils reduced the number of fungal spores at both concentrations, in comparison to that of the control treatment. Lorenzetti et al. (2011) observed that cinnamon, lemon grass, clove, and eucalyptus essential oils at $200 \mu \mathrm{L} \mathrm{L}^{-1}$ reduced the in vitro growth of the fungus Colletotrichum gloeosporioides by more than $30 \%$; however, at $1,000 \mu \mathrm{L} \mathrm{L}^{-1}$, the effect of the oils on the fungus improved, and the growth reduction reached $100 \%$ for cinnamon, lemon grass, and clove oils, and $71 \%$ for eucalyptus oil. In the present study, cinnamon,

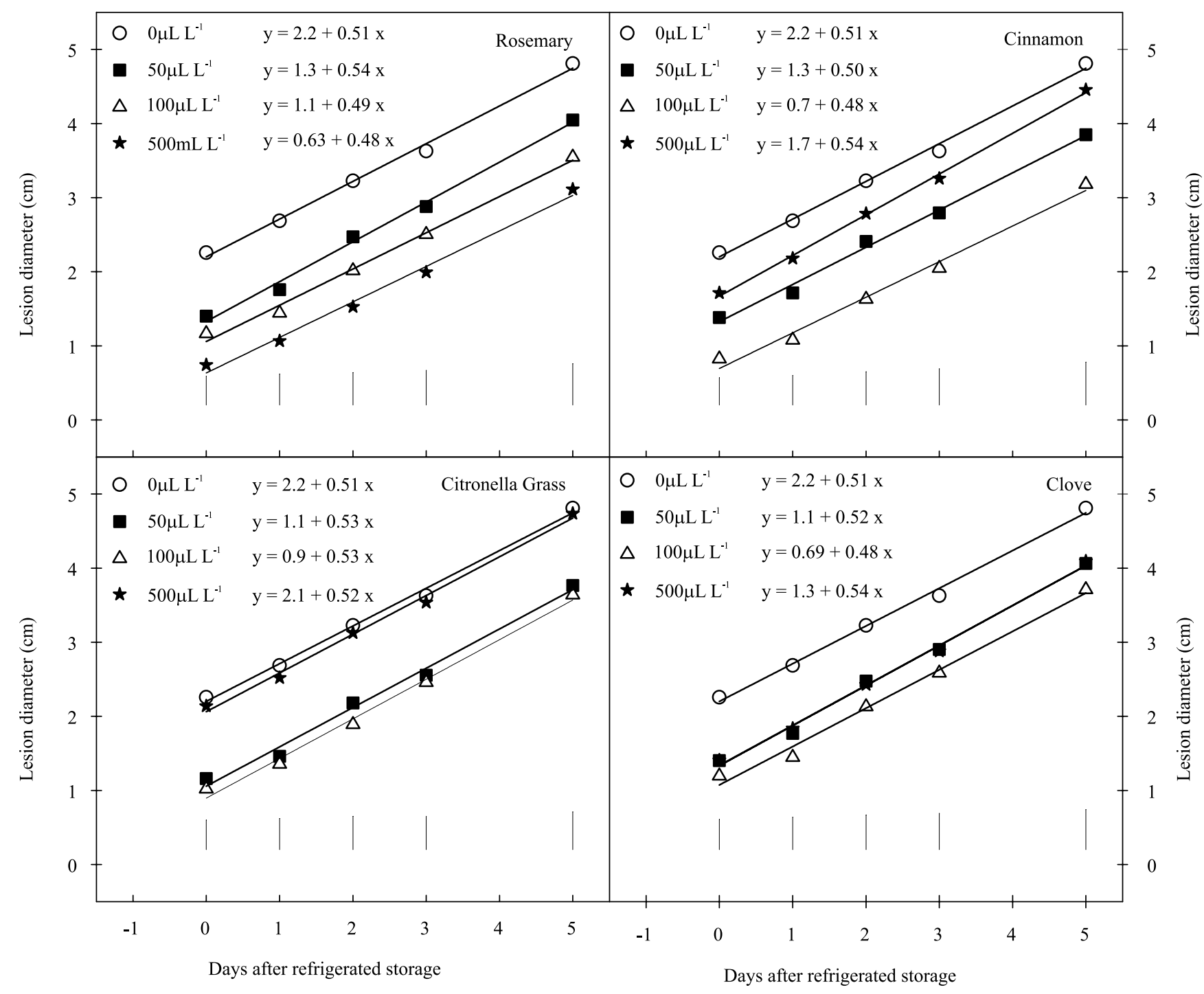

Figure 1. Diameter of blue mold (Penicillium expansum) lesions in 'Fuji' apples (Malus domestica) treated with volatilized rosemary (Rosmarinus officinalis), cinnamon (Cinnamomum zeylacium), citronella grass (Cymbopogon winterianus), and clove (Syzigium aromaticum) essential oils at $0,50,100$, and $500 \mu \mathrm{L} \mathrm{L}^{-1}$ concentrations, after 30 days of cold storage $\left(0 \pm 0.5^{\circ} \mathrm{C}\right.$ and $90 \pm 2 \% \mathrm{RH})$, followed by five days at room temperature $\left(23 \pm 5^{\circ} \mathrm{C}\right.$ and $\left.70 \pm 5 \% \mathrm{RH}\right)$ without essential oils. Vertical bars indicate the least significant difference between the means, by the Tukey's test, at 5\% probability. RH, relative humidity. 
clove, and citronella grass oils inhibited in about $80 \%$ the growth of P. expansum at $100 \mu \mathrm{L} \mathrm{L}^{-1}$ (Figure 1).

'Fuji' apples treated with different essential oils showed a smaller diameter of blue mold lesions than the nontreated fruit; nonetheless, the effect of the oils varied according to concentration used, days of treatment, and evaluation time. The concentration increase of the rosemary essential oil resulted in a reduced lesion diameter in fruit treated both for 30 and 2 days (Figures 1 and 2).

In the performed evaluation, as soon as the fruit were removed from the chamber (day 0), the reductions of $P$. expansum growth in fruit treated for 30 days with rosemary essential oil at 50,100 , and $500 \mu \mathrm{L} \mathrm{L}^{-1}$ were 38,48 , and $67 \%$, respectively. After five days at room temperature, a greater inhibition of fungus growth was observed at the highest oil concentrations, with

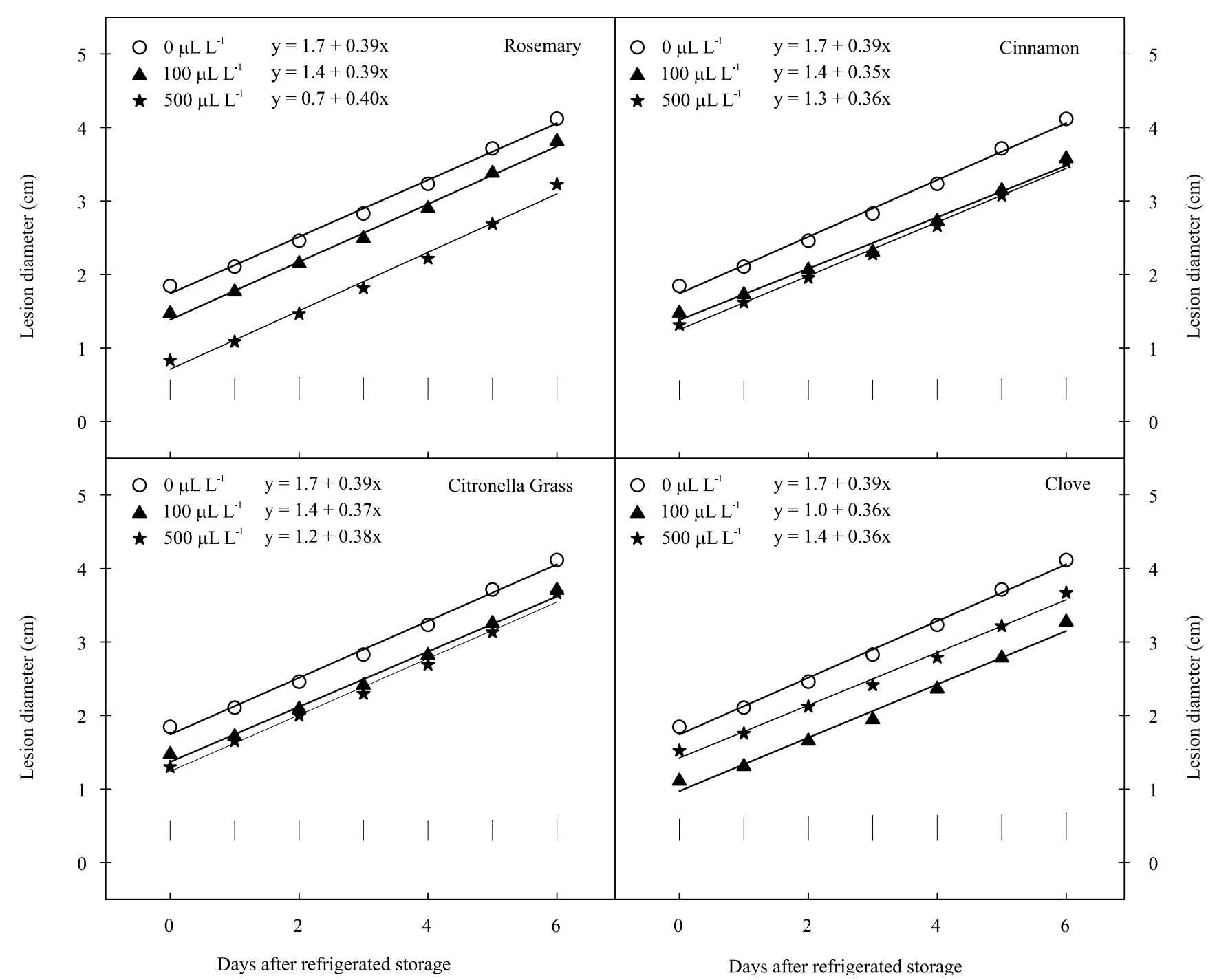

Figure 2. Blue mold (Penicillium expansum) lesion diameter in 'Fuji' apples (Malus domestica) treated with volatilized rosemary (Rosmarinus officinalis), cinnamon (Cinnamomum zeylacium), citronella grass (Cymbopogon winterianus), and clove (Syzigium aromaticum) essential oils at 0,100 , and $500 \mu \mathrm{L} \mathrm{L}^{-1}$ concentrations, after 45 days of cold storage $\left(0 \pm 0.5^{\circ} \mathrm{C}\right.$ and $95 \% \mathrm{RH})$, with two days in the presence of the oils, followed by six days at room temperature $\left(23 \pm 4^{\circ} \mathrm{C}\right.$ and $\left.70 \pm 5 \% \mathrm{RH}\right)$. Vertical bars indicate the least significant difference between the means, by the Tukey's test, at 5\% probability. RH, relative humidity. 
a 26 and $35 \%$ reduction of blue mold growth, in the treatments at 100 and $500 \mu \mathrm{L} \mathrm{L}^{-1}$, respectively.

The treatment with the highest concentration $\left(500 \mu \mathrm{L} \mathrm{L}^{-1}\right)$ of cinnamon and citronella grass essential oils, when applied for 30 days, did not reduce the development of blue mold. However, the cinnamon essential oil at $100 \mu \mathrm{L} \mathrm{L}^{-1}$ provided $64 \%$ inhibition of fungus growth (Figure 1). The treatment with citronella grass oil at $500 \mu \mathrm{L} \mathrm{L}^{-1}$ did not differ from the control in the evaluation times. The lesion diameters of the fruit treated with citronella grass oil at 50 and $100 \mu \mathrm{L} \mathrm{L}^{-1}$ did not differ from each other; lesions were inhibited around $50 \%$ at both concentrations, when the fruit were removed from the chamber, and slightly more than $20 \%$ after five days at room temperature. The treatment with clove essential oil reduced the diameter of the blue mold lesions, in comparison to fruit without treatment with this essential oil; however, there was no significant difference between the tested concentrations of this oil $\left(50,100\right.$, and $\left.500 \mu \mathrm{L} \mathrm{L}^{-1}\right)$.

In fruit treated with rosemary oil for two days, the inhibition of blue mold development was 20 and $55 \%$ for the concentrations of 100 and $500 \mu \mathrm{L} \mathrm{L}^{-1}$, respectively, by the time the fruit were removed from the chamber. After six days at room temperature, the inhibition of fungus growth reached 7 and $22 \%$ at the respective concentrations (Figure 2).

The clove oil at $500 \mu \mathrm{L} \mathrm{L}^{-1}$ was less efficient in reducing the blue mold development than at $100 \mu \mathrm{L} \mathrm{L}^{-1}$; however, at both concentrations, the fruit showed lower lesion diameters than that of the control (Figure 2).

The treatment with the cinnamon and citronella grass oils reduced the diameter of blue mold lesions, but no significant difference was observed between the concentrations of 100 and $500 \mu \mathrm{L} \mathrm{L}^{-1}$ (Figure 2).

The growth of the lesions throughout the days, at room temperature, was linear with no observed difference in the daily growth rate of the rot lesions among all oils, concentrations, and treatment times (Figures 1 and 2). The fungus growth rate ranged from 0.36 to $0.54 \mathrm{~cm}$ per day, depending on the essential oil and treatment time.

The inhibitory effect of fungus growth was more evident in vitro than in vivo for most essential oils, which was also reported by other authors (Plotto et al., 2003; Sun et al., 2014; Shao et al., 2015). Shao et al. (2015) reported that the incorporation of clove essential oil into the culture medium significantly reduced the in vitro growth of $P$. digitatum, and they observed extravasation of the cellular fluid and alteration of the hyphae morphology of the fungus. However, these authors were unable to reproduce the same results in citrus fruit artificially infected with the fungus, and immersed in clove essential oil at concentrations of 500, 1,000, or $2,000 \mu \mathrm{L} \mathrm{L}^{-1}$. Carvacrol, trans-cinnamaldehyde, and cinnamaldehyde are compounds mostly found in clove, cinnamon, oregano, and thyme essential oils. These oils showed antimicrobial activity on Escherichia coli and Penicillium digitatum in blueberry fruit, but there were more substantial effects on the inhibition of microbial growth in vitro (Sun et al., 2014).

The effects of the essential oils depend on their composition and concentration, the microbial species, and time and form (immersion or volatilization) of treatment (Droby et al., 2008; Wang et al., 2012). The mechanisms of antimicrobial action of essential oils are not fully understood, but some have been proposed. There is evidence that the lipophilic characteristic of the oils allows of the expansion of the plasma membrane of microbial cell, and the increase of membrane fluidity and permeability, inhibiting the cellular respiration, and altering the ion transport process and extravasation of cellular contents (Fadli et al., 2012). Alteration of cell morphology and cell growth block may also occur (Tao et al., 2014).

According to Jiménez-Del Rio \& Vélez-Pardo (2004), the essential oils penetrate the cells because of the increased permeability of the membrane, causing damage mainly to the membrane of the mitochondria. Through the change in the flow of electrons in the transport chain, they produce free radicals, which oxidize and damage lipids, proteins, and DNA. Some phenolic or terpenoid compounds, present in essential oils, undergo oxidation by the contact with these free radicals; therefore, these compounds produce highly reactive phenoxy radicals, which can cause even greater damage to microbial cells (Jiménez-Del Rio \& VélezPardo, 2004). When antioxidant molecules present in essential oils - such as phenolic and terpenoid compounds - interact with reactive forms of oxygen, they are converted into pro-oxidants. Pro-oxidants have the ability to oxidize lipids, proteins, and DNA, causing a severe damage to various organelles of microorganism cells, compromising the entire antioxidant defense of the microbial cell (Bakkali et al., 2008). 
Although the direct action of the oils on the microorganisms is known, they can also act as inductors of resistance. Pereira et al. (2012) observed an increased activity of the enzymes peroxidase and chitinase, after spraying coffee plants with $1,000 \mu \mathrm{L} \mathrm{L}^{-1}$ of citronella grass essential oil, which promoted a reduced growth of Hemileia vastatrix and Cercospora caffeicola in 47 and 29\%, respectively. Shao et al. (2015) observed an increase of the defense enzymes chitinase and phenylalanine ammonia-lyase in citrus fruit after immersion in a solution with clove essential oil at 500 $\mu \mathrm{L} \mathrm{L}^{-1}$ concentration. These authors observed also a reduced diameter of green mold lesions ( $P$. digitatum), and attributed this result to the synergistic effect of the antimicrobial and inducing resistance actions of the essential oil.

Irrespective of the concentrations employed, the evaluated essential oils had no substantial effect on the poststorage quality of 'Fuji' apples (pulp firmness, soluble solids content, titratable acidity, and background color of the epidermis), in fruit treated for both 30 and 2 days (Table 3 ).

Table 3. Color of the epidermis, soluble solids content (SS), titratable acidity (TA) and pulp firmness (PF) of 'Fuji' apple (Malus domestica) fruit treated with volatilized essential oils, for 2 or 30 days under refrigeration, and maintained for another five months under refrigeration $\left(0 \pm 0.5^{\circ} \mathrm{C}\right.$ and $90 \pm 2 \% \mathrm{RH}$ ), followed by 7 days at room temperature $\left(23 \pm 4^{\circ} \mathrm{C} \text { and } 70 \pm 5 \% \mathrm{RH}\right)^{(1)}$.

\begin{tabular}{|c|c|c|c|c|c|c|}
\hline \multirow{2}{*}{$\begin{array}{l}\text { Oil } \\
\text { essential }\end{array}$} & \multicolumn{3}{|c|}{ Color of the epidermis } & \multirow{2}{*}{$\begin{array}{l}\text { SS } \\
(\%)\end{array}$} & \multirow{2}{*}{$\begin{array}{l}\mathrm{TA} \\
(\%)\end{array}$} & \multirow{2}{*}{$\begin{array}{l}\mathrm{PF} \\
(\mathrm{N})\end{array}$} \\
\hline & $\mathrm{L}$ & $\mathrm{C}$ & $\mathrm{h}^{\circ}$ & & & \\
\hline & \multicolumn{6}{|c|}{ Essential oil treatment for 30 days } \\
\hline Rosemary & 70.4 & 42.6 & 97.3 & 13.8 & 0.122 & 59.4 \\
\hline Cinnamon & 71.0 & 43.0 & 100.1 & 13.9 & 0.129 & 63.4 \\
\hline Citronella grass & 70.5 & 42.8 & 98.5 & 13.8 & 0.109 & 59.7 \\
\hline Clove & 69.3 & 42.6 & 99.4 & 13.5 & 0.125 & - \\
\hline Mean & 70.4 & 42.9 & 99.1 & 13.7 & 0.118 & 60.8 \\
\hline \multirow[t]{2}{*}{ SD } & 1.40 & 0.93 & 2.36 & 0.63 & 0.013 & 2.23 \\
\hline & \multicolumn{6}{|c|}{ Essential oil treatment for 2 days } \\
\hline Rosemary & 69.6 & 41.3 & 96.0 & 13.8 & 0.135 & 63.8 \\
\hline Cinnamon & 68.9 & 42.0 & 94.7 & 13.7 & 0.145 & 69.0 \\
\hline Citronella grass & 70.0 & 41.7 & 95.5 & 13.5 & 0.146 & 68.5 \\
\hline Clove & 69.9 & 41.7 & 96.5 & 13.3 & 0.138 & 64.3 \\
\hline Mean & 69.6 & 41.7 & 95.7 & 13.6 & 0.141 & 66.4 \\
\hline SD & 0.50 & 0.29 & 3.18 & 0.22 & 0.005 & 2.73 \\
\hline
\end{tabular}

(1)Means in the columns, in each treatment time, do not differ by Tukey's test, at $5 \%$ probability. Values referring to the averages obtained with the essential oil concentrations of 0,100 and $500 \mu \mathrm{L} \mathrm{L}^{-1}$, and $0,50,100$ and $500 \mu \mathrm{L} \mathrm{L}^{-1}$ for 2 and 30 days, respectively. $\mathrm{RH}$, relative humidity; SD, standard deviation.

\section{Conclusions}

1. Rosemary (Rosmarinus officinalis), cinnamon (Cinnamomum zeylacium), citronella grass (Cymbopogon winterianus), and clove (Syzigium aromaticum) essential oils are composed mainly of eucalyptol, eugenol, citronellal, and eugenol, respectively.

2. The essential oils at 100 , and $1,000 \mu \mathrm{L} \mathrm{L}^{-1}$ reduce the growth, number, and viability of Penicillium expansum spores 24 hours after the induction to germination; they also reduce the diameter of blue mold lesions in apple after 30 days of cold storage, regardless of the evaluation time, except for the citronella oil, at $500 \mu \mathrm{L} \mathrm{L}^{-1}$.

3 . There is no change in the soluble solids, titratable acidity, pulp firmness, or the background color of the epidermis of 'Fuji' apples subjected to treatments with essential oils after cold storage for five months, followed by seven days at room temperature.

\section{References}

ARGENTA, L.C.; VIEIRA, M.J.; SOUZA, F. de; PEREIRA, W.S.P.; EDAGI, F.K. Diagnóstico da qualidade de maçãs no mercado varejista brasileiro. Revista Brasileira de Fruticultura, v.37, p.48-63, 2015. DOI: 10.1590/0100-2945-047/14.

BAKKALI, F.; AVERBECK, S.; AVERBECK, D.; IDAOMAR, M. Biological effects of essential oils - a review. Food and Chemical Toxicology, v.46, p.446-475, 2008. DOI: 10.1016/j. fct.2007.09.106.

BOMFIM, N. da S.; NAKASSUGI, L.P.; OLIVEIRA, J.F.P.; KOHIYAMA, C.Y.; MOSSINI, S.A.G.; GRESPAN, R.; NERILO, S.B.; MALLMANN, C.A.; ABREU FILHO, B.A.; MACHINSKI Jr., M. Antifungal activity and inhibition of fumonisin production by Rosmarinus officinalis L. essential oil in Fusarium verticillioides (Sacc.) Nirenberg. Food Chemistry, v.166, p.330336, 2015. DOI: 10.1016/j.foodchem.2014.06.019.

CASTRO, H.G.; BARBOSA, L.C.A.; LEAL, T.C.A.B.; SOUZA, C.M.; NAZARENO, A.C. Crescimento, teor e composição do óleo essencial de Cymbopogon nardus (L.). Revista Brasileira de Plantas Medicinais, v.9, p.55-61, 2007.

DROBY, S.; EICK, A.; MACARISIN, D.; COHEN, L.; RAFAEL, G.; STANGE, R.; MCCOLUM, G.; DUDAI, N.; NASSER, A.; WISNIEWSKI, M.; SHAPIRA, R. Role of citrus volatiles in host recognition, germination and growth of Penicillium digitatum and Penicillium italicum. Postharvest Biology and Technology, v.49, p.386-396, 2008. DOI: 10.1016/j.postharvbio.2008.01.016.

FADLI, M.; SAAD, A.; SAYADI, S.; CHEVALIER, J.; MEZRIOUI, N.-E.; PAGÈS, J.-M.; HASSANI, L. Antibacterial activity of Thymus maroccanus and Thymus broussonetii essential oils against nosocomial infection-bacteria and their synergistic 
potential with antibiotics. Phytomedicine, v.19, p.464-471, 2012. DOI: 10.1016/j.phymed.2011.12.003.

FERNANDEZ, M.R. Manual para laboratório de fitopatologia. Passo Fundo: Embrapa-CNPT, 1993. 128p. (Embrapa-CNPT. Documentos, 6).

FISHER, K.; PHILLIPS, C. Potential antimicrobial uses of essential oils in food: is citrus the answer? Trends in Food Science and Technology, v.19, p.156-164, 2008. DOI: 10.1016/j. tifs.2007.11.006.

HOET, S.; STÉVIGNY, C.; HÉRENT, M.-F.; QUETINLECLERCQ, J. Antitrypanosomal compounds from the leaf essential oil of Strychnos spinosa. Planta Medica, v.72, p.480482, 2006. DOI: $10.1055 / \mathrm{s}-2005-916255$.

JIMÉNEZ-DEL RÍO, M.; VÉLEZ-PARDO, C. Transition metalinduced apoptosis in lymphocytes via hydroxyl radical generation, mitochondria dysfunction, and caspase-3 activation: an in vitro model for neurodegeneration. Archives of Medical Research, v.35, p.185-193, 2004. DOI: 10.1016/j.arcmed.2004.01.001.

LORENZETTI, E.R.; MONTEIRO, F.P.; SOUZA, P.E.; SOUZA, R.J.; SCALICE, H.K.; DIOGO JR., R.; PIRES, M.S.O. Bioatividade de óleos essenciais no controle de Botrytis cinerea isolado de morangueiro. Revista Brasileira de Plantas Medicinais, v.13, p.619-627, 2011. Número especial. DOI: 10.1590/S1516-05722011000500019.

MASOTTI, V.; JUTEAU, F.; BESSIÈRE, J.M.; VIANO, J. Seasonal and phenological variations of the essential oil from the narrow endemic species Artemisia molinieri and its biological activities. Journal of Agricultural and Food Chemistry, v.51, p.7115-7121, 2003. DOI: 10.1021/jf034621y.

MEDEIROS, H.A. Diagnóstico e caracterização de perdas por podridões pós-colheita em maçãs. In: ENCONTRO NACIONAL SOBRE FRUTICULTURA DE CLIMA TEMPERADO, 14., 2015, Fraiburgo. Anais. Caçador: EPAGRI, 2015. v.1, p.48-52.

MILLER, B.D.; RIGDON, C.E.; ROBINSON, T.J.; HEDBERG, C.; SMITH, K.E. Use of global trade item numbers in the investigation of a salmonella newport outbreak associated with blueberries in Minnesota, 2010. Journal of Food Protect, v.76, p.762-769, 2013. DOI: 10.4315/0362-028X.JFP-12-407.

NERI, F.; MARI, M.; BRIGATI, S. Control of Penicillium expansum by plant volatile compounds. Plant Pathology, v.55, p.100-105, 2006. DOI: 10.1111/j.1365-3059.2005.01312.x.

PEREIRA, R.B.; LUCAS, G.C.; PERINA, F.J.; RIBEIRO JÚNIOR, P.M.; ALVES, E. Citronella essential oil in the control and activation of coffee plants defense response against rust and brown eye spot. Ciência e Agrotecnologia, v.36, p.383-390, 2012. DOI: $10.1590 /$ S1413-70542012000400001.

PLOTTO, A.; ROBERTS, D.D.; ROBERTS, R.G. Evaluation of plant essential oils as natural postharvest disease control of tomato (Lycopersicon esculentum). Acta Horticulturae, v.628, p.737-745, 2003. DOI: 10.17660/ActaHortic.2003.628.93.

POPA, I.; HANSON, E.J.; TODD, E.C.D.; SCHILDER, A.C.; RYSER, E.T. Efficacy of chlorine dioxide gas sachets for enhancing the microbiological quality and safety of blueberries. Journal of Food Protection, v.70, p.2084-2088, 2007. DOI: 10.4315/0362-028X-70.9.2084.

RIBEIRO, F.W.M.; LAURENTINO, L. da S.; ALVES, C.R.; BASTOS, M. do S.R.; COSTA, J.M.C. da; CANUTO, K.M.; FURTADO, R.F. Chemical modification of gum arabic and its application in the encapsulation of Cymbopogon citratus essential oil. Journal of Applied Polymer Science, v.132, p.41519-41525, 2015. DOI: $10.1002 /$ app.41519.

SHAO, X.; CAO, B.; XU, F.; XIE, S.; YU, D.; WANG, H. Effect of postharvest application of chitosan combined with clove oil against citrus green mold. Postharvest Biology and Technology, v.99, p.37-43, 2015. DOI: 10.1016/j.postharvbio.2014.07.014

SILVEIRA, J.P.G.; AMARANTE, C.V.T.; STEFFENS, C.A.; CORREA, T.R. PAES, F.N. Potencial produtivo e qualidade de frutos de macieiras tratadas com giberelina e inibidor da biossíntese de giberelinas. Revista Brasileira de Fruticultura, v.36, p.771-779, 2014. DOI: 10.1590/0100-2945-352/13.

SUN, X.; NARCISO, J.; WANG, Z.; FERENCE, C.; BAI, J.; ZHOU, K. Effects of chitosan-essential oil coatings on safety and quality of fresh blueberries. Journal of Food Science, v.79, p.955960, 2014. DOI: 10.1111/1750-3841.12447.

TAO, N.; JIA, L.; ZHOU, H. Anti-fungal activity of Citrus reticulata Blanco essential oil against Penicillium italicum and Penicillium digitatum. Food Chemistry, v.153, p.265-271, 2014. DOI: 10.1016/j.foodchem.2013.12.070.

VARUGHESE, T.; UNNIKRISHNAN, P.K.; DEEPAK, M.; BALACHANDRAN, I.; SHREE, A.B.R. Chemical composition of the essential oils from stem, root, fruit and leaf of Piper longum Linn. Journal of Essential Oil Bearing Plants, v.19, p.52-58, 2016. DOI: 10.1080/0972060X.2015.1119065.

WANG, H.; TAO, N.; HUANG, S.; LIU, Y. Effect of Shatangju (Citrus reticulata Blanco) essential oil on spore germination and mycelium growth of Penicillium digitatum and P. italicum. Journal of Essential Oil Bearing Plants, v.15, p.715-723, 2012. DOI: 10.1080/0972060X.2012.10644111.

Received on November 28, 2016 and accepted on August 9, 2017

Pesq. agropec. bras., Brasília, v.53, n.5, p.547-556, May 2018

DOI: 10.1590/S0100-204X2018000500003 